\title{
ANALISIS MATERI AJAR MEMBACA DALAM BUKU DEUTSCH IST EINFACH
}

\author{
Sri Rahmawati Indah ${ }^{1}$ dan Nurming Saleh ${ }^{2}$ \\ Jurusan Pendidikan Bahasa Asing, Fakultas Bahasa dan Sastra \\ Universitas Negeri Makassar \\ Email: sri.rahmawati@gmail.com ${ }^{1}$
}

\begin{abstract}
ABSTRAK
Tujuan penelitian ini adalah untuk mengetahui kesalahan yang terdapat pada teks dan latihanlatihan membaca dalam buku Deutsch ist Einfach yang digunakan di kelas XI Sekolah Menengah Atas. Penelitian ini adalah penelitian deskriptif data dikumpulkan menggunakan teknik dokumentasi. Instrumen yang digunakan dalam penelitian ini adalah teks-teks dan latihan membaca dengan tema die Familie dalam buku Deutsch ist Einfach. Data yang diperoleh dalam penelitian ini dianalisis menggunakan analasisis deskriptif. Hasil analisis data penelitian ini menunjukan bahwa terdapat 4 ( empat ) kategori kesalahan yaitu diksi, tata bahasa, ortografi dan petunjuk kerja latihan dan 17 ( tujuh belas ) kesalahan secara keseluruhan yaitu kosakata, tata bahasa, huruf kapital, diksi, tanda baca dan petunjuk kerja latihan yang terdapat dalam buku Deutsch ist Einfach.
\end{abstract}

Kata Kunci: Materi Ajar, Keterampilan Membaca, Buku Deutsch Ist Einfach

\begin{abstract}
The purpose of this research is to know the errors that occur in the text and exercises in the Deutsch ist Einfach book in the class XI High School. This research is descriptive research data using documentation technique. The instruments used in this study are texts and exercises with Die Familie theme in Deutsch ist Einfach book. The data used in this study were analyzed using descriptive analysis. The results of the data analysis show that there are 4 (four) categories of errors, namely diction, grammar, orthography and work guidance and 17 (seventeen) errors in general like vocabulary, grammar, capital letters, diction, punctuation and training work instructions already in Deutsch ist Einfach book.
\end{abstract}

Keywords: Learning Material, Reading Skill, Deutsch ist Einfach book

\section{PENDAHULUAN}

Membaca merupakan salah satu kompetensi berbahasa yang diajarkan dalam proses pengajaran bahasa khususnya bahasa Jerman. Peranan membaca dalam pembelajaran bahasa Jerman sangat penting sebagaimana pentingnya ketiga aspek berbahasa lainnya yaitu aspek menyimak (Hören), berbicara (Sprechen), dan menulis (Schreiben). Keempat aspek ini saling berkaitan dalam mencapai tujuan pembelajaran yag telah ditetapkan.

Dalam pembelajaran bahasa Jerman khususnya pembelajaran membaca, buku ajar 
memegang peranan penting, karena buku ajar merupakan salah satu sarana belajar yang mendukung keberhasilan proses pembelajaran. Selain itu, materi ajar berfungsi sebagai salah satu pedoman terhadap kompetensi dan keterampilan yang harus dikuasai oleh peserta didik dalam memahami materi atau konsep yang diajarkan (Jufri, 2007; Jufri, 2017).

Buku ajar bahasa Jerman yang digunakan dalam pembelajaran seharusnya sesuai dengan Kurikulum Tingkat Satuan Pendidikan (KTSP) yang berlaku. Di dalam Kurikulum Tingkat Satuan Pendidikan (KTSP) memuat empat kompetensi berbahasa, yaitu mendengarkan (Hören), berbicara (Sprechen), membaca (Lesen), dan menulis (Schreiben). Guru dapat menemukan berbagai buku ajar bahasa Jerman yang telah beredar banyak digunakan. Salah satu buku yang digunakan dalam pembelajaran membaca di SMA adalah buku Deutsch ist Einfach. Buku ini telah memenuhi standar Kurikulum Tingkat Satuan Pendidikan dan dijadikan sebagai buku pegang guru dan siswa dalam pembelajaran bahasa Jerman.

Berdasarkan isi buku Deutsch ist einfach masih ditemukan beberapa kesalahan berupa kesalahan tata bahasa, kosakata dan penulisan bahasa Jerman yang terdapat dalam buku Deutsch ist einfach. Oleh karena itu, buku Deutsch ist einfach perlu ditelaah dan dianalisis bacaan-bacaan yang tersusun dalam buku Deutsch ist einfach. Pada umumnya materi ajar yang tidak sesuai dengan karakteristik dan kemampuan siswa dapat menjadi faktor penyebab timbulnya kesulitan yang dialami siswa dalam memahami materi yang diajarkan, bahkan dapat menyebabkan kurangnya motivasi siswa dalam membaca teks-teks bahasa Jerman.
Terdapat beberapa permasalahan yang dialami oleh guru dalam proses pembelajaran, baik itu berkaitan dengan model atau strategi pembelajaran (Mantasiah dkk, 2017; Qalbi, 2017; Yusri dkk, 2018; Romadloni, 2017; Qudus \& Yusri, 2017) maupun yang yang berkaitan dengan pemilihan materi ajar yang tepat dalam rangka membantu siswa mencapai kompetensi. Hal ini disebabkan oleh kenyataan bahwa dalam kurikulum atau silabus, materi bahan ajar hanya dituliskan secara garis besar dalam bentuk materi pokok. Materi ajar secara garis besar terdiri dari pengetahuan, keterampilan, dan sikap yang harus dipelajari siswa dalam rangka mencapai standar kompetensi yang telah ditentukan. Secara terperinci, jenis-jenis materi pembelajaran terdiri dari pengetahuan (fakta, konsep, prinsip, prosedur) keterampilan, dan sikap atau nilai.

Materi pembelajaran merupakan faktor eksternal siswa yang mampu memperkuat motivasi internal untuk belajar. Salah satu cara yang mampu mempengaruhi aktivitas pembelajaran adalah dengan memasukkan materi pembelajaran dalam aktivitas tersebut. Materi pembelajaran yang didesain secara lengkap, dalam arti ada unsur media dan sumber belajar yang memadai akan mempengaruhi suasana pembelajaran sehingga proses belajar yang terjadi pada diri siswa menjadi lebih optimal. Dengan materi pembelajarn yang didesain secara baik dan dilengkapi isi dan ilustrasi yang menarik dan akan menstimulasi siswa untuk memanfaatkan materi pembelajaran sebagai materi belajar atau sebagai sumber belajar.

Materi pembelajaran mempunyai peran yang sangat penting dalam kegiatan pembelajaran. Materi pembelajaran dapat berperan sebagai materi belajar mandiri, apabila materi pembelajaran didesain secara 
lengkap, materi pembelajaran ini dilengkapi dengan tujuan pembelajaran atau kompetensi yang akan dicapai, materi pembelajaran yang diuraikan dalam kegiatan belajar, ilustrasi media, prosedur pembalajaran, latihan yang harus dikerjakan dilengkapi rambu jawaban, tes formatif dilengkapi kunci jawaban, umoan balik, daftar pustaka.

Materi ajar yang digunakan pada pengajaran membaca bahasa Jerman sekarang ini sebagian besar tidak berorientasi kepada materi bacaan-bacaan yang sebenarnya dibutuhkan oleh siswa dalam membangun imajinasi dan pengetahuan mereka untuk memahami isi bacaan. Kreativitas dan inovasi pengajar dalam memilih materi bacaan bahasa Jerman yang sesuai dengan kebutuhan siswa diharapkan dapat meminimalisasi kesulitan dan ketidakmampuan siswa memahami teksteks bacaan bahasa Jerman.

Berdasarkan hasil observasi yang dilakukan selama proses praktik pengalaman lapangan (PPL II) di SMA Negeri 2 Makassar, diketahui bahwa buku ajar yang digunakan yakni buku Deutsch ist einfach masih terdapat kesalahan-kesalahan dalam penulisan tatabahasa, kosata dan penulisan. Hal tersebut di atas didukung oleh hasil penelitian yang telah dilakukan oleh Lutfi (2016) membuktikan bahwa analisis materi ajar dalam buku Deutsch ist einfach kelas XI masih terdapat kesalahan dari segi gramatik dan kosakata. Namun, termasuk dalam kategori cukup. Selanjutnya Sandy (2016) menyatakan bahwa analisis buku Deutsch ist einfach belum memenuhi kriteria buku ajar yang baik. Kemudian hasil penelitian Puspitasari (2016) membuktikan bahwa analisis buku Deutsch ist einfach untuk SMA termasuk dalam kategori cukup.

\section{ANALISIS KESALAHAN BERBAHASA}

Pembelajaran bahasa pada dasarnya adalah proses mempelajari bahasa. Dalam mempelajari suatu bahasa tentu tidak luput dari kesalahan baik dari segi lisan maupun tulisan. Analisis kesalahan adalah pengkajian segala aspek kesalahan. Hastuti (2003:73) mengemukakan bahwa analisis kesalahan adalah proses didasarkan pada analisis orang yang sedang belajar dengan suatu objek yang jelas. Adapun objek yang dimaksud dalam penelitian ini merupakan buku mata pelajaran bahasa Jerman yakni buku deutsch ist einfach. Crystal dalam Ayuningsih (2012:5) mengemukakan bahwa analisis kesalahan adalah suatu teknik untuk mengidentifikasi, mengklasifikasi, dan menginterpretasikan secara secara sistematik kesalahan-kesalahan yang dilakukan oleh peserta didik yang sedang mempelajari bahasa asing atau bahasa kedua dengan menggunakan teori atau prosedur linguistik

Senada dengan pendapat di atas, Azis (2007:24) mengemukakan bahwa analisis kesalahan adalah segala bentuk kesalahan dalam bahasa atau tidak sesuai dengan kaidah penggunaan bahasa yang baik dan benar yang harus diperbaiki atau dikoreksi agar penggunaannya lebih baik dan benar. Dari beberapa pendapat di atas, dapat disimpulkan bahwa analisis kesalahan adalah pengkajian segala aspek kesalahan untuk mengetahui kesalahan-kesalahan dalam bahasa dan hasil analisis kesalahan tersebut dapat digunakan sebagai dasar dalam memperbaiki komponen proses belajar bahasa asing berikutnya.

Analisis kesalahan berbahasa adalah suatu prosedur kerja, sehingga dalam menganalisis kesalahan tersebut membutuhkan langkah-langkah yang sistematis ahar hasil yang diperoleh dari analisis kesalahan tersebut memberikan 
manfaat dalam proses pembelajaran bahasa. Ellis dalam Tarigan (2011:60) menjelaskan bahwa langkah untuk menganalisis kesalahan meliputi pengumpulan sampel, pengidentifikasian kesalahan, penjelasan kesalahan, pengklasifikasian kesalahan dan pengevaluasian kesalahan.

Tarigan (2013:63) menjelaskan tentang langkah-langkah kerja baru analisis kesalahan melalui penyeleksian, pengurutan, dan penggabungan hasil modifikasi tersebut diambil inti sarinya yang terdiri atas mengumpulkan data, mengidentifikasi dan mengklasifikasi kesalahan, memperingkat kesalahan, menjelaskan kesalahan, memperkirakan atau memprediksi daerah atau hal kebahasaan yang rawan, dan mengoreksi kesalahan. Dari beberapa pendapat di atas dapat disimpulkan bahwa langkah-langkah dalam menganalisis kesalahan yaitu pengumpulan sampel, pengidentifikasian kesalahan, penjelasan kesalahan, pengklasifikiasian kesalahan dan pengevaluasian kesalahan.

\section{MATERI AJAR}

Materi ajar pada dasarnya adalah "isi" dari kurikulum, yakni berupa mata pelajaran atau bidang studi dengan topik/sub topik dan rinciannya. Secara umum isi kurikulum itu dapat dipilah menjadi tiga unsur utama, yaitu logika (pengetahuan tentang benar-salah; berdasarkan prosedur keilmuan), etika (pengetahuan tentang baik-buruk) berupa muatan nilai moral, estetika (pengetahuan tentang indah-jelek) berupa muatan nilai seni.

Materi ajar adalah salah satu komponen sistem pembelajaran yang memegang peranan penting dalam membantu siswa mecapai Standar Kompetensi dan Kompetensi Dasar atau tujuan pembelajaran yang telah ditentukan. Salah satu tugas pendidik adalah menyediakan suasana belajar yang menyenangkan. Pendidik harus mencari cara untuk membuat pembelajaran menjadi menyenangkan. Salah satu cara untuk membuat pembelajaran menjadi menyenangkan adalah dengan menggunakan materi ajar yang menyenangkan pula, yaitu materi ajar yang dapat membuat siswa merasa tertarik dan senang mempelajari materi ajar.

Sumantri (2016:217) "mengatakan materi ajar merupakan salah satu sumber belajar dalam bentuk konsep, prinsip, definisi, gugus isi atau konteks, data maupun fakta, proses, nilai, kemampuan, dan keterampilan. Materi yang dikembangkan hendaknya mengacu pada program dalam silabus yang membelajarkannya disesuaikan dengan kebutuhan dan lingkungan peserta didik".

Menurut Haling (2007:173) Materi ajar adalah segala bentuk bahan yang digunakan untuk membantu guru/instruktur dalam melaksanakan kegiatan belajar mengajar. Bahan yang dimaksud dapat berupa bahan tertulis maupun yang tidak tertulis. Menurut Iskandarwassid dan Sunendar (2011:171), materi ajar adalah seperangkat informasi yang harus diserap peserta didik melalui pembelajaran yang menyenangkan. Peserta didik harus benar-benar merasakan manfaat materi itu setelah ia mempelajarinya.

Pendapat lain mengenai materi ajar oleh Sanjaya (2008:141) Materi ajar (Learning materials) adalah segala sesuatu yang menjadi isi kurikulum yang harus dikuasai oleh siswa sesuai dengan kompetensi dasar dalam rangka pencapaian standar kompetensi setiap mata pelajaran dalam satuan pendidikan tertentu. Prastowo (2017:17) mengemukakan bahwa "Materi ajar pada dasarnya merupakan segala bahan (baik informasi, alat maupun teks) yang disusun secara sistematis, yang menampilkan sosok 
utuh dari kompetensi yang akan dikuasai siswa dan digunakan dalam proses pembelajaran dengan tujuan perencanaan dan penelaahan implementasi pembelajaran.

Dari beberapa pendapat di atas, dapat disimpulkan bahwa materi ajar adalah sebagai segala bentuk bahan yang disusun secara sistematis yang memungkinkan siswa dapat belajar secara mandiri dan dirancang sesuai kurikulum yang berlaku. Dengan adanya materi ajar, guru akan lebih runtut dalam mengajarkan materi kepada siswa dan tercapai semua kompetensi yang telah ditentukan sebelumnya. Dalam membuat sebuah materi ajar seorang guru harus memperhatikan aspek-aspek penting yang menunjang keberhasilan peserta didik untuk memahami materi. Selain itu seorang guru juga harus memperhatikan prinsip-prinsip dalam pengembangan materi ajar itu sendiri, sehingga materi ajar tersebut sesuai dengan standar kompetensi dan kompetensi dasar yang akan dicapai oleh peserta didik.

Prastowo (2012:317) menjelaskan “ ada beberapa prinsip yang perlu diperhatikan dalam penyusunan materi pembelajaran. Prinsip-prinsip dalam pemilihan materi pembelajaran meliputi prinsip relevansi, konsistensi, dan kecukupan. Ketiga penerapan prinsip-prinsip tersebut dipaparkan sebagai berikut: (1) prinsip relevansi, artinya keterkaitan. Materi pembelajaran hendaknya relevan atau ada kaitan dengan pencapaian standar kompetensi dan kompetensi dasar. Dengan prinsip dasar ini, guru akan mengetahui apakah materi yang hendak diajarkan tersebut materi fakta, konsep, prinsip, prosedur, aspek sikap atau aspek psikomotorik sehingga pada gilirannya guru terhindar dari kesalahan pemilihan jenis materi yang tidak relevan dengan pencapaian standar kompetensi dan kompetensi dasar; (2) prinsip konsistensi, artinya keajegan. Jika kompetensi dasar yang harus dikuasai siswa empat macam, makan materi ajar yang harus diajarkan juga harus meliputi empat macam; (3) prinsip kecukupan, artinya materi yang diajarkan hendaknya cukup memadai dalam membantu siswa menguasai kompetensi dasar yang diajarkan. Materi tidak boleh terlalu sedikit, dan tidak boleh terlalu banyak. Jika terlalu sedikit akan kurang membantu mencapai standar kompetensi dan kompetensi dasar. Sebaliknya, jika terlalu banyak akan membuang-buang waktu dan tenaga yang tidak perlu untuk mempelajarinya.

Menurut Taba dalam Harjanto (2002:69) prinsip-prinsip pemilihan materi pelajaran sebagai berikut: (1) kesahihan dan kebermaknaan materi dalam kaitannya dengan perkembangan ilmu dan teknologi; (2) keseusaian dengan kenytaan yang ada dan hidup dalam masyarakat; (3) keseimbangan antara keluasaan (breadht) dan kedalaman (depth) materi tersebut; (4) memungkinkan digunakan sebagai tujuan belajar; (5) dapat tidaknya dipelajari (learability) dan keseuaian (adaptability) dengan pengalaman siswa; (6) kecocokanya denga kebutuhan dan minat siswa.

Pendapat di atas, dapat disimpulkan bahwa prinsip-prinsip materi ajar yaitu: (1) relevansi yang berarti ada kaitan dengan pencapaian standar kompetensi dan kompetensi dasar; (2) konsistensi; (3) kecukupan artinya materi yang diajarkan hendaknya cukup memadai dalam membantu siswa menguasai kompetensi dasar yang diajarkan; (4) kesahihan dan kebermaknaan materi.

\section{METODE PENELITIAN}

Penelitian ini menggunakan variabel tunggal yaitu analisis materi ajar membaca 
pada buku Deutsch ist einfach. Penelitian ini adalah penelitian kualitatif. Hasil penelitian ini berupa mendeskripsikan kesesuaian materi ajar dengan kaidah tata bahasa, kosakata dan menulis dalam Buku Deutsch ist einfach untuk SMA kelas XI semester 1 dengan Kurikulum Tingkat Satuan Pendidikan (KTSP 2006).

Data yang digunakan dalam penelitian ini adalah teks-teks dan latihan membaca yang terdapat dalam buku ajar Deutsch ist einfach untuk SMA kelas XI semester 1 tema die Familie. Teknik pengumpulan data yang digunakan dalam penelitian ini adalah teknik dokumentasi. Teknik dokumentasi yang dimaksud adalah teks-teks dan latihan membaca yang bertemakan die Familie yang terdapat dalam buku ajar. Adapun langkahlangkah (prosedur) pengumpulan data dalam penelitian ini adalah:

1. Mengelompokan materi ajar membaca yang terdapat dalam buku ajar Deutsch ist einfach.

2. Menentukan materi bacaan dan latihan yang terdapat dalam buku ajar Deutsch ist einfach.

3. Mengklasifikasi kesesuaian kaidah tata bahasa, kosakata, dan penulisan (ortografi)

4. Menentukan ketidaksesuaian kaidah tata bahasa, kosakata dan penulisan (ortografi) yang terdapat dalam buku Deutsch ist einfach, kemudian mendekripsikan kesalahan-kesalahan yang ditemukan dalam buku Deutsch ist einfach tersebut.

Data dalam penelitian ini dianalisis dengan menggunakan metode analisis kesalahan yang dikemukakan oleh Ellis dalam Tarigan (2011:60).

Adapun langkah-langkah yang digunakan adalah:
1. Pengumpulan, yaitu pengumpulan data materi ajar yang ada dalam buku deutsch ist einfach

2. Mengidentifikasi, yaitu memberikan tanda pada kesalahan-kesalahan yang terdapat dalam materi ajar.

3. Menjelaskan, yaitu mengambarkan letak kesalahan dan jenis kesalahan,

4. Mengklasifikiasi, yaitu mengelompokkan data yang diperoleh kedalam jenis kesalahan penggunaan tata bahasa, kosa kata dan menulis yang terdapat dalam buku deutsch ist einfach.

5. Evaluasi yaitu memperbaiki kesalahan yang tidak sesuai dengan kaidah tata bahasa, kosakata, dan ortografi yang terdapat dalam buku deutsch ist einfach.

\section{HASIL DAN PEMBAHASAN}

Pada bagian ini akan dibahas tentang jenis kesalahan tata bahasa, kosakata dan penulisan yang terdapat dalam buku Deutsch ist einfach tema die Familie dalam aspek membaca. Data yang diuraikan dalam hasil penelitian ini yaitu data tentang kesalahan yang terdapat dalam buku Deutsch ist einfach, khususnya tata bahasa, kosakata dan penulisan.

1. Materi (Der Familiestammbaum)

Materi “ Der Familiestammbaum” yang terdapat pada halaman 7 ditemukan adanya kesalahan dalam materi ini yaitu pada bagian petunjuk kerja latihan yang tertulis dalam buku Deutsch ist einfach yaitu "Lest den Text und ergänzt den Stammbaum von Laura!" Yang seharusnya di ganti dengan kalimat "Lesen Sie den Text und ergänzen Sie den Stammbaum von Laura!'. Secara penulisan kalimat tersebut sudah sesuai dengan tatabahasa Jerman. Namun, jika ditinjau dari sudut pandang etika kalimat tersebut tidak tepat .Hal itu ditandai dengan penggunaan 
kata lest dimana kata tersebut digunakan dalam kalimat perintah untuk orang kedua jamak, yakni ihr. Kata lesen berasal dari kata dasar les kemudian dikonjugasikan dengan subjek ihr sehingga mendapatkan tambahan akhiran t, sehingga menjadi lest.

Instruksi tersebut seharusnya diganti menjadi tuturan yang sopan (höflich), yakni “ Lesen Sie den Text und ergänzen Sie den Stammbaum von Laura"! Instruksi ini sesuai dengan penggunaan kalimat perintah bahasa Jerman yang ditandai dengan penggunaan Endung-en yang ditambahkan pada kata dasar les dan ergänz yang diikuti kata ganti Sie (anda).

2. Materi ( Familien in Deutschland und Indonesien)

Dalam teks yang terdapat pada materi II

(Dua) Familien in Deutschland und Indonesien halaman 15 ditemukan beberapa kesalahan yaitu:

a. Petunjuk kerja latihan tidak jelas, tidak ditemukan adanya kalimat instruksi pada bacaan. Kesalahan ini tentu membuat pembaca tidak memahami tujuan dari bacaan yang terdapat pada teks tersebut. Oleh karena itu sebaiknya dicantumkan kalimat instruksi seperti "Lesen Sie die Texte".

b. Tata bahasa pada kalimat Mein Vater ist Automechaniker und meine Mutter ist eine Angestellte in einer Firma. Kesalahan pada kalimat tersebut ditandai dengan penggunaan kata depan in yang seharusnya menggunakan kata depan $\underline{\text { bei }}$ Kalimat tersebut diterima secara komunikastif, tetapi tidak sesuai dengan tatabahasa Jerman, karena kata depan bei sudah menunjukan bahwa die Mutter merupakan karyawan di sebuah perusahan tersebut. Sedangkan in pada frasa in der firma bermakna bahwa
Mutter memiliki kedudukan yang sama dengan atasan. Jadi kalimat tersebut seharusnya "Mein Vater ist Automechaniker und meine Mutter ist eine Angestellte bei der Firma".

c. Penggunaan tanda baca yaitu penggunaan titik pada kalimat "ich mache selbst das Mittagessen und esse allein zu Mittag. Aber das macht nicht". Pada kalimat ini kata penghubung aber dalam aturan bahasa Jerman seharusnya diikuti oleh tanda baca koma (,) tidak diikuti dengan tanda baca titik. Pada kalimat tersebut penulis buku Deutsch ist einfach masih menggunakan pola bahasa Indonesia.

d. Penulisan pada kata pengubung aber yang tertulis dalam bacaan yaitu $\underline{A} b e r$ huruf kapital yang seharusnya pada kata penghubung aber tidak ditulis menggunakan A huruf kapital.

3. Materi (Familien in Deutschland und Indonesien)

Dalam teks yang terdapat pada materi III Familien in Deutschland und Indonesien pada halaman 17 terdapat beberapa kesalahan yaitu:

a. Tata bahasa yang terdapat pada kalimat " Ich möchte wissen die Familie in Indonesien" merupakan bentuk kesalahan pembuatan kalimat Modal verben yang seharusnya "Ich möchte die Familie in Indonesien wissen".

b. Penggunaan tanda baca yaitu penggunaan titik (.) pada kalimat "manchmal bin ich traurig. Aber zum Glück”. Seharusnya setelah penggunaan kata penghubung aber harus diikuti dengan tanda baca koma (,)

c. Selain itu masih terdapat kesalahan pada penulisan pada kata pengubung aber yang tertulis dalam bacaan yaitu $\underline{A} b e r$ huruf kapital yang seharusnya pada kata 
penghubung aber tidak menggunakan huruf kapital.

4. Materi (Familien in Deutschland und Indonesien)

Dalam teks yang terdapat pada materi IV halaman 19 Familien in Deutschland und Indonesien ditemukan sebuah kesalahan penulisan pada kata Cousinen dalam dialog ke 6 (Ardi) " Ja, ich habe einen Onkel, eine Tante, einen Neffe, zwei Nichten, einen Cousin und 3 Cousinnen" jika diterjemahakan kedalam bahasa Jerman kata ini tidak memiliki arti karena kelebihan penulisan huruf $\underline{\mathrm{n}}$ pada kata tersebut yang seharusnya “ $J a$, ich habe einen Onkel, eine Tante, einen Neffe, zwei Nichten, einen Cousin und 3 Cousinen."

5. Materi Familien in Deutschland und Indonesien

Dalam teks yang terdapat pada materi $\mathrm{V}$ (Lima) Familien in Deutschland und in Indonesien pada halaman 20 terdapat beberapa kesalahan yaitu :

a. Bagian Petunjuk kerja latihan ditemukan kesalahan yaitu pada kalimat "Lest den Dialog” Secara penulisan kalimat tersebut sudah sesuai dengan tata bahasa Jerman. Namun, jika ditinjau dari sudut pandang etika kalimat tersebut tidak tepat .Hal itu ditandai dengan penggunaan kata lest dimana kata tersebut digunakan dalam kalimat perintah untuk orang kedua jamak, yakni ihr. Kata lesen berasal dari kata dasar les kemudian dikonjugasikan dengan subjek $i h r$ sehingga mendapatkan tambahan Endung t sehingga menjadi lest. Instruksi tersebut seharusnya diganti menjadi tuturan yang lebih sopan (Höflich), yakni "Lesen Sie den Dialog". Instruksi ini dianggap lebih di tandai dengan penggunaan Endung-en yang ditambahkan pada kata dasar les dan yang diikuti kata ganti Sie (anda). Karena buku deutsch ist einfach tidak hanya dibaca oleh siswa melainkan guru.

b. Kesalahan tanda baca koma (,) pada dialog 1 (Anette) "Sagt mal Ardi, Rani, und Ali, wen telfoniert ihr am meisten?" namun, jika dilihat dari pola penulisan tanda baca dalam kalimat tersebut menggunakan pola bahasa Indonesia. Buku bahasa Jerman pada umumnya harus mengikuti pola penulisan dalam bahasa Jerman. Yaitu sebelum kata penghubung und tidak perlu menggunakan tanda baca koma (,).

c. Kesalahan lain yang terdapat dalam teks tersebut adalah kesalahan penulisan pada kata telfoniert yang terdapat dalam kalimat "Sagt mal Ardi, Rani, und Ali, wen telfoniert ihr am meisten?". kata telfoniert tersebut seharusnya diubah menjadi kata telefoniert yakni Ditambahkan huruf e.

6. Materi (Probleme in der Familie)

Dalam teks yang terdapat pada materi VI halaman 31 "Probleme in der Familie pada halaman 31 terdapat beberapa kesalahan yaitu:

a. Bagian petunjuk kerja latihan sudah sesuai dengan kaidah dan penulisan dalam bahasa Jerman. Namun, dalam petunjuk kerja latihan masih perlu adanya penambahan serta perbaikan pada kalimat “Lest den Text und macht die Übungen!" kalimat ini sudah sesuai dengan tata bahasa Jerman namun ditinjau dari segi etika kalimat ini kurang tepat, yang seharusnya di ubah menjadi kalimat yang lebih Sopan (Höflich) yakni: "Lesen Sie den Text und machen Sie die Übungen!".

b. Bagian paragraf kedua (Vera) terdapat kesalahan pemilihan kata yang terdapat pada kalimat " Filmstar ist ihr 
Traumberuf' karena kata Filmstar merupakan serapan dari bahasa inggris bukan kata baku bahasa Jerman. Yang seharusnya diganti dengan kalimat "Schauspielerin ist ihr Traumberuf".

7. Materi (Bitte, Verbote, und Befehle)

Dalam teks yang terdapat pada materi VII halaman 47 "Bitte, Verbotte, und Befehle" pada halaman 47 terdapat beberapa kesalahan yaitu :

a. Materi" Bitte, Verbote, und Befehle" terdapat kesalahan penulisan tanda baca koma (,) sebelum kata penguhubung und. Kalimat ini menggunakan pola penulisan dalam bahasa indonesia yang seharusnya buku deutsch ist einfach harus menggunakan pola penulisan dalam bahasa jerman. Seperti "Bitte, Verbote und Befehle" yang setelah kata penghubung und tidak perlu menambahkan tanda baca koma (,)

b. Kesalahan dalam kalimat perintah bentuk Sie form pada kalimat Kaufen sie bitte auch einen Drücker! pada kalimat tersebut tertulis (s) huruf kecil pada personal pronomen sie. Yang dimana Sie yang dimaksud adalah untuk menunjukan orang pertama ketiga tunggal yang seharusnya ditulis huruf kapital ( $\underline{\mathrm{S}})$ pada personal pronomen Sie.

c. Kesalahan lain yang terdapat dalam teks tersebut adalah kesalahan tata bahasa Jerman pada frasa eine Handy yang terdapat dalam kalimat "Bitte kaufen Sie eine Handy für mich!" Karena artikel dari Handy adalah das yang jika diubah menjadi unbestimmte artikel menjadi ein.

Oleh karena itu kalimat tersebut seharusnya menjadi "Bitte kaufen Sie ein Handy für mich!'”.

\section{KESIMPULAN}

Berdasarkan analisis data dan pembahasan hasil penelitian dapat disimpulkan bahwa ditemukan beberapa kesalahan yang terdapat dalam buku Deutsch ist Einfach pada materi ajar membaca. Adapun kesalahan tersebut meliputi kesalahan dalam penulisan yakni tanda baca koma, kosakata dan huruf kapital selain itu terdapat kesalahan Diksi, tatabahasa, dan petunjuk penyelesaian kalimat perintah. Jadi dalam buku Deutsch ist einfach terdapat 17 ( Tujuh belas) kesalahan secara keseluruhan.

\section{DAFTAR PUSTAKA}

Ayuningsih, Faridhotun Dwi. 2012. Analisis Kesalahan Berbahasa pada Penulisan Pengalaman Pribadi Siswa Kelas X A SMK Batik 2 Surakarta, Surakarta. Skripsi. Fakultas Keguruan dan Ilmu Pendidikan Universitas Muhammadiyah Jakarta. ( Online ) di akses pada tanggal 13 juni 2017 pukul 20:12

Azis, Abdul. 2009. Analisis Kesalahan Berbahasa. Makassar. Badan Penerbit UNM.

Harjanto. 2011. Perencanaan Pengajaran. Jakarta Rineka Cipta

Hastuti, Sri. 2003. Sekitar Analisis Kesalahan Berbahasa Indonesia. Yogyakarta: Gava Media.

Iskandarwassid dan Sunendar,Dadang. 2011. Srategi Pembelajaran Bahasa. Bandung: PT Remaja Rosdakarya Offset.

Jufri, J. 2007. Metode Penelitian Bahasa. Sastra dan Budaya.

Jufri, J., 2017. Strategi Pembelajaran Bahasa.

Kasim. 201. Deutsch ist einfach. Jakarta: PT

Tiga Serangkai Pustaka Mandiri

Mantasiah, R., Juffri, J., \& Yusri, Y. 2017.

Keefektifan Model Pembelajaran Jaring 
Laba-Laba (Webbed) dalam Sumantri, Syarif Muhammad. (2016). Strategi Keterampilan Menulis Karangan Pembelajaran Teori dan Praktik di Sederhana Bahasa Jerman. INSANI, Tingkat Pendidikan Dasar. Jakarata: PT 20(2).

Raja Grafindo Persada.

Prastowo, Andi. 2012. Menyusun Rencana

Pelaksanaan Pembelajaran (RPP)

Tematik Terpadu. Yogyakarta: Diva Pres.

Qalbi, U. N., Mantasiah, R., Jufri, J., \& Yusri, Y. 2017. Efektivitas Model Pembelajaran Kooperatif Tipe Teams Games Tournaments dalam Keterampilan Menulis Bahasa Jerman Siswa Kelas XII IPA SMA Negeri 1 Bontonompo Kabupaten Gowa. INSANI, 20(1).

Qudus, M. and Yusri, Y., 2017. Keefektifan Penggunaan Metode Audio Lingual dalam Pembelajaran Kemampuan Menyimak Bahasa Jerman. INSANI, 20(2).

Romadloni, A., \& Mantasiah, R. Intercultural approach in foreign language learning to improve students' motivation. Senior Editors, 61.

Sanjaya, Wina. 2010. Perencanaan dan Desain Sistem Pembelajaran. Jakarta: Kencana Prenanda Media Group.

Tarigan, Djago dan Lilis Siti Sulstyaningsih. 1996/1997, Analisis Kesalahan Berbahasa. Departemen Pendidikan dan Kebudayaan Direktorat Jenderal Pendidikan Dasar dan Menengah Bagian Proyek Penataran Guru SLTP setara D-III

Tarigan, H. Guntur . 2008. Membaca sebagai Suatu Keterampilan Berbahasa. Bandung: Angkasa.

Tarigan, Henri Guntur dan Djago Tarigan. 2011. Pengajaran Analisis Kesalahan Berbahasa Bandung: Penerbit Angkasa Bandung.

Yusri, Y., Mantasiah, R., \& Jufri, J. 2018. The Use Of Two Stay Two Stray Model in English Teaching to Increase Student's Learning Outcome. Journal Of Advanced English Studies, 1(1), 39-43. 